\title{
グリシン及び塩化ナトリウムによる大腸菌リン脂質組成の変化*1
}

(平成元年 6 月 9 日受理)

竜口和恵*2 坂本次郎*3
李 在根 ${ }^{* 4}$ 堤 将和

\section{Effects of Treatments with Glycine and/or Sodium Chloride on Phospholipid Composition of Escherichia coli}

\author{
Kazue Tatsuguchi ${ }^{* 2}$, Jiroh Sakamoto ${ }^{* 3}$, Jea-Kyum LeE ${ }^{* 4}$ and Masakazu Tsutsumi ${ }^{* 5}$ \\ (*2) Seinan Jogakuin Junior College: 1-3-2, Ibori, Kokurakita-ku Kitakyushu, Japan; \\ ${ }^{* 3}$ Ajinomoto Co Ltd. Central Research Laboratory: 1-1, Suzuki-cho, Kawasaki-ku, \\ Kawasaki, Japan; ${ }^{* 4}$ University of Suncheon: 315, Megok-Dong, Suncheon, \\ Cheonnan, Korea; ${ }^{5}$ Department of Agrobiological Resources, Faculty \\ of Agriculture, Ibaraki University: 3998, Ami, Ami-cho, Inashiki, \\ Ibaraki, Japan)
}

\begin{abstract}
The combined antimicrobial effect of glycine and sodium chloride against Escherichia coli was studied by examining the effects of glycine and/or sodium chloride on the membrane components, protein and phospholipid. The membrane proteins from the cells treated with glycine and/or sodium chloride were analyzed by SDS-polyacrylamide gel electrophoresis. No change of membrane protein composition was detected. The cells of $E$. coli were labeled with ${ }^{14} \mathrm{C}$-acetate, and were treated with glycine and/or sodium chloride. The labeled membrane phospholipid was analyzed by TLC, and the radioactivities of the respective lipid spots were measured. Cardiolipin (CL) content in phospholipid was increased by treatment with sodium chloride. Glycine had no effect on phospholipid composition, but combined treatment with glycine and sodium chloride further enhanced the increase of CL. In contrast, free fatty acid (FFA) increased instead of CL when cells grown in sodium chloride- or glycine-containing medium were treated with glycine or sodium chloride. CL, diphosphatidylglycerol, is a membrane stabilizer. FFA is a degradation product of membrane phospholipid, and perturbs the membrane.

From the above results and these facts, we concluded that the combined antimicrobial effects of glycine and sodium chloride against Escherichia coli resulted from damage to the membrane.
\end{abstract}

(Received June 9, 1989)

Key words: グリシン glycine；塩化ナトリウム sodium chloride；大腸菌 Escherichia coli；抗菌 力併用効果 combined antimicrobial effect; カルジオリピン cardiolipin; 遊離脂肪酸 free fatty acid

著者らはグリシンと塩化ナトリウム $(\mathrm{NaCl})$ の抗菌力 併用効果の発現に, 菌体の膜構造の変化が関係している

*1 グリシンと塩化ナトリゥムの抗菌力併用効果（第 2 報）

$*^{2}$ 西南女学院短期大学: 北九州市小倉北区井堀 1-3-2

*3 味の素(株)中央研究所：川崎市川崎区鈴木町 1-1

*4 順天大学：大韓民国全羅南道順天市梅谷洞 315

*5 茨城大学農学部：茨城県稲敷郡阿見町阿見 3998
ことを認めた1)ので，本報では膜を構成するタンパク質 とリン脂質について，その組成の変化と抗菌力発現との 関係を検討した。

\section{実験材料及び方法}

\section{1. 使用菌株とその培養}

前報1のように，供試菌株としては Escherichia coli IFO3301 を用い，培地，培養条件なども同様に行った。 


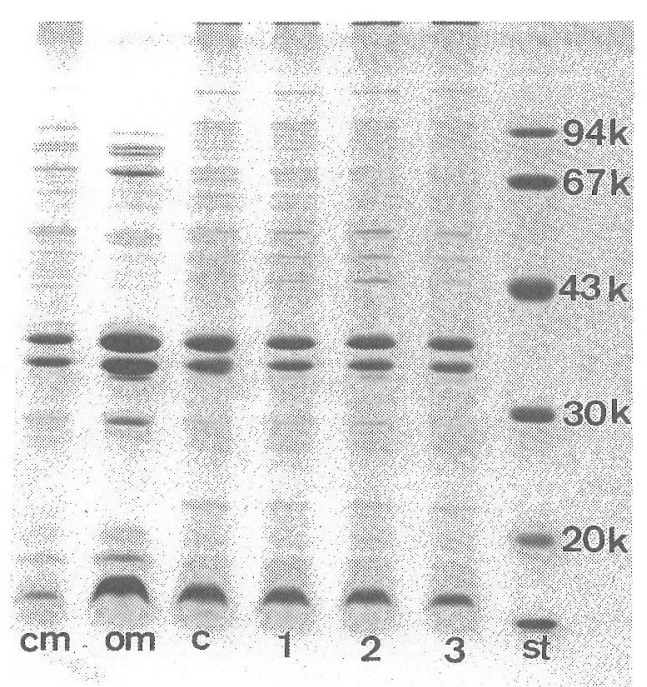

Fig. 1. SDS-polyacrylamidegel electrophoresis of membrane protein from the cells treated with glycine

cm: cytoplasmic membrane; om: outer membrane; c: control; $1 \sim 3$ : concentration of glycine (\%); st: standard protein.

2. 試薬

a) スフェロプラスト膜調製用試萫

トリスハイドロキシアミノメタン (Tris), エチレンシ アミン四酢酸二ナトリウム(EDTA) は和光純薬工業 (株)製，特級品を，ショ糖は半井化学薬品(株)製，特級 品を，卵白リゾチームはメルク社のものを，デオキシリ ボヌクレアーゼ(DNase) はシグマ社のすのを用いた。

b) 電気泳動用試薬

アクリルアミド， $N, N^{\prime}$ メチレンビスアクリルアミド

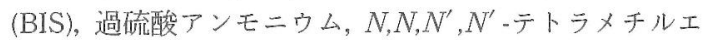
チレンジアミン，ラウリル硫酸ナトリウム(SDS)，2-メ ルカプトエ夕ノール，コマージブリリアントブルー R$250(\mathrm{CBB})$ は半井化学薬品(株)製, 電気泳動用試薬を, 酢酸, イソプロピルアルコール (IPA) は半井化学薬品 (株)製，特級品を，グリセリン，ブロムフェノールブル 一は和光純蔝工業(株)製，特級品を用いた。また，標準 タンパク質としてはつァルマシア社の低分子量用キット を用いた。

c) 脂質の放射ラベル及び分析用試薬

$\left\{2-{ }^{14} \mathrm{C}\right\}$ 一酢酸ナトリウム（放射比活性， $1.8 \mathrm{mCi} /$ ml） は New England Nuclear社のものを非放射性の酢 酸ナトリウஃでU.b $\mathrm{mCi} / \mathrm{m}$ に希粎して用いた。トルエ ン, 2,5 ージフェニルオキサゾール (DPO) は半井化学薬品 (株)製, 液体シ・チレーション用を, クロロホルム, メ タノールは半井化学薬品(株)製，特級品を用いた。薄層 クロマトグラフィー (TLC) にはメルク社の Kiesel gel H

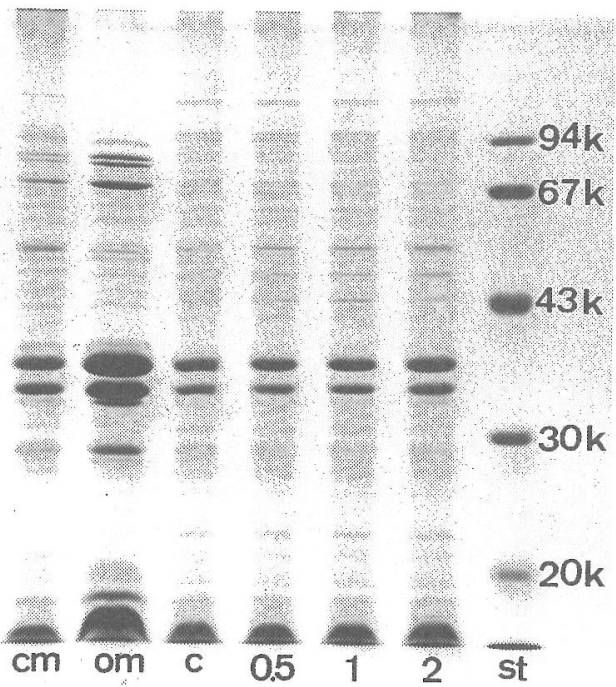

Fig. 2. SDS-polyacrylamidegel electrophoresis of membrane protein from the cells grown in $2 \%$ sodium chloride containing medium

The cells were treated with $0.5 \% \sim 2 \%$ glycine.

Abbreviations are similar as shown in Fig. 1.

60 を用いた。

d) 脂肪酸分析用試薬

脂肪酸のメチル化試薬としては和光純薬工業(株)製の ナトリウムメチラートを，その他，抽出用としては半井 化学薬品(株)製, 特級品の石油エーテル, クロロホルム, メタノールを用いた。 また，脂肪酸標準品としては，シ グマ社製のミリスチン酸 $(14: 0)$ ，パルミチン酸 $(16: 0)$, パルミトオレイン酸 $(16: 1)$ ，ステアリン酸 $(18: 0)$ ，才 レイン酸 $(18: 1)$ 安用いた。

\section{3.スフェロプラスト膜の調製と精製}

対数增殖期後期まで培养し.た培养液 $450 \mathrm{ml}$ を遠心分 離 $\left(7,000 \times \mathrm{g}, 5\right.$ 分， $\left.4^{\circ}\right)$ により集め, 脱イオン水で 1 回 洗浄した後，OD 660 值が 0.4 となるように，脱イオン

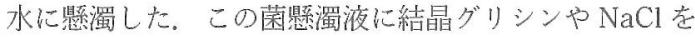

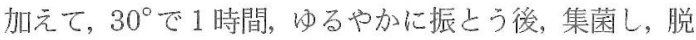
イオン水 $17.8 \mathrm{ml}$ に䀣濁して，EDTA-リゾチーム法常に よりスフェロプラストを調製した。こ扎を遠心分離

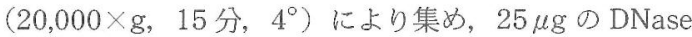
を含む $5 \mathrm{mM}$ 塩化マグネシウム $50 \mathrm{ml}$ にテフロンホモ ジイザーを用いて十分䀣濁させた。混入している菌体 を，1,500× $\mathrm{g} ， 10$ 分間の遠心分離により除いた後, $20,000 \times g, 20$ 分の遠心分離により，スフェロプラスト 膜を集め,さらに，0.5 M, $2 M$ の不連続ショ糖密度勾配 遠心 $\left(74,000 \times g, 2\right.$ 時間, $\left.4^{\circ}\right)$ で精製し, タンパク質分 析用の試料とした。 

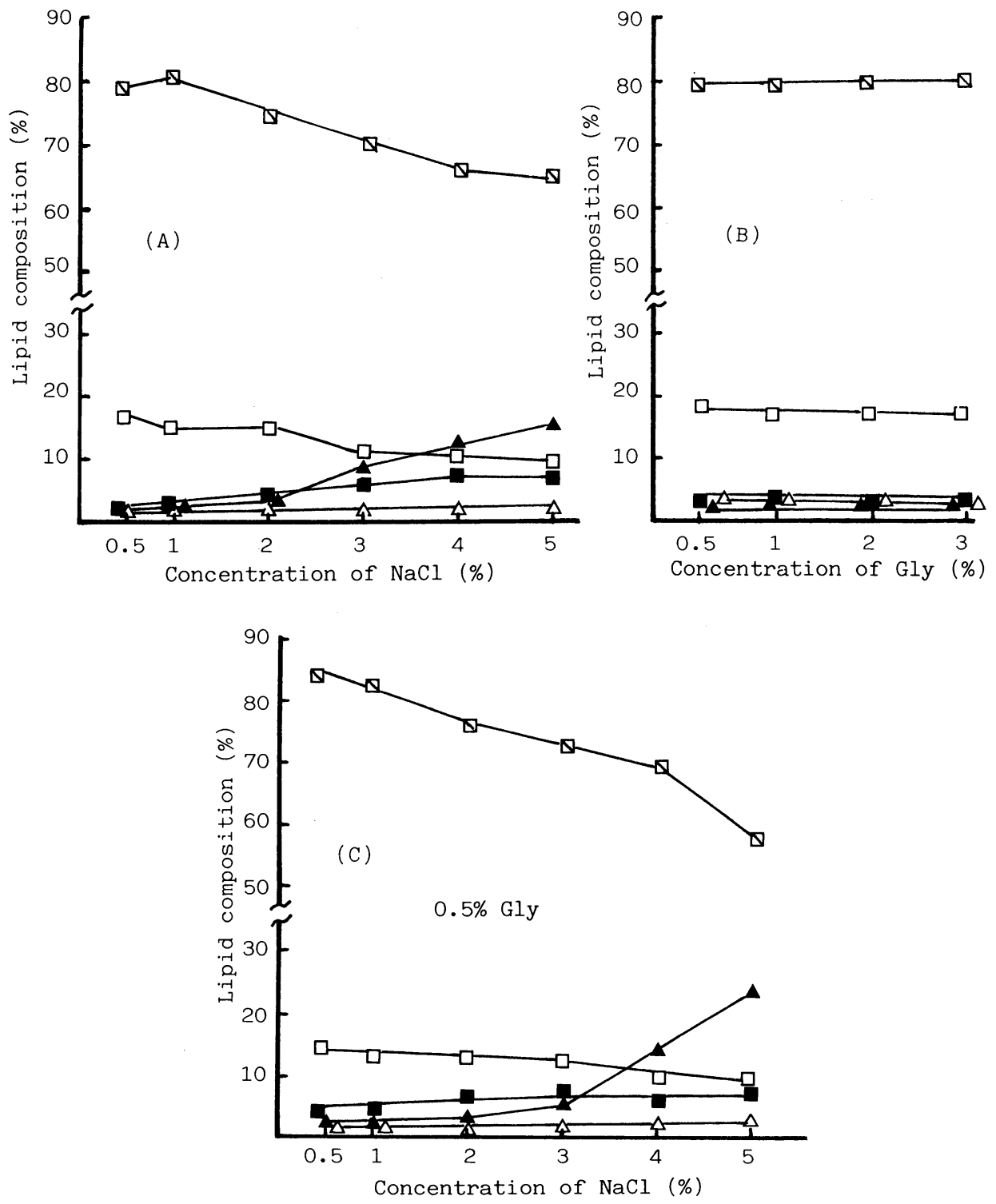

Fig. 3. Lipid composition of $E$. coli treated with sodium chloride and/or glycine

(A): treatment with sodium chloride; (B): treatment with glycine; (C): treatment with sodium chloride plus $0.5 \%$ glycine; $-\square-$ : phosphatidylethanolamine; $-\square-$ : phosphatidylglycerol; $-\mathbf{\Delta}-$ : cardiolipin; $-\square$ : free fatty acid; $-\triangle-$ : lysophospholipid

\section{SDS-ポリアクリルアミド電気泳動 (SDS-PAGE)}

Lugtenberg の方法 ${ }^{3)}$ 従い, SDS-PAGE を行った。 ただし泳動ゲル組成はアクリルアミド，11\%-BIS, 0.2\%, 添加タンパク質量は約 $20 \mu \mathrm{g}$ とした．泳動後のゲルの染 色・固定・脱色は 0.04\% CBB-25\% IPA-10\% 酢酸で 1 夜， $0.004 \%$ CBB-10\% IPA-10\% 䣷酸で，6〜7 時間， 10\%酢酸で 48 時間行った。

\section{5. 脂質の放射能ラベル，抽出及び分析}

${ }^{14} \mathrm{C}$-酢酸ナトリウムを培地 $10 \mathrm{ml}$ につき $20 \mu \mathrm{Ci}$ 加え て対数増殖期中期まで培養して菌体をラベルした後, グ リシンあるいは $\mathrm{NaCl}$ ， または併用の処理を $30^{\circ}$ で 1 時 間行って集菌・洗浄し, 少量の脱イオン水に懸濁した。 この菌懸濁液から Bligh とDyer の方法 ${ }^{4}$ により脂質抽 出を行い, 窒素ガスを吹き付けて濃縮し, TLC の試料と した. TLCプレートにはシリカゲル Hを $0.3 \mathrm{~mm}$ 厚さ 

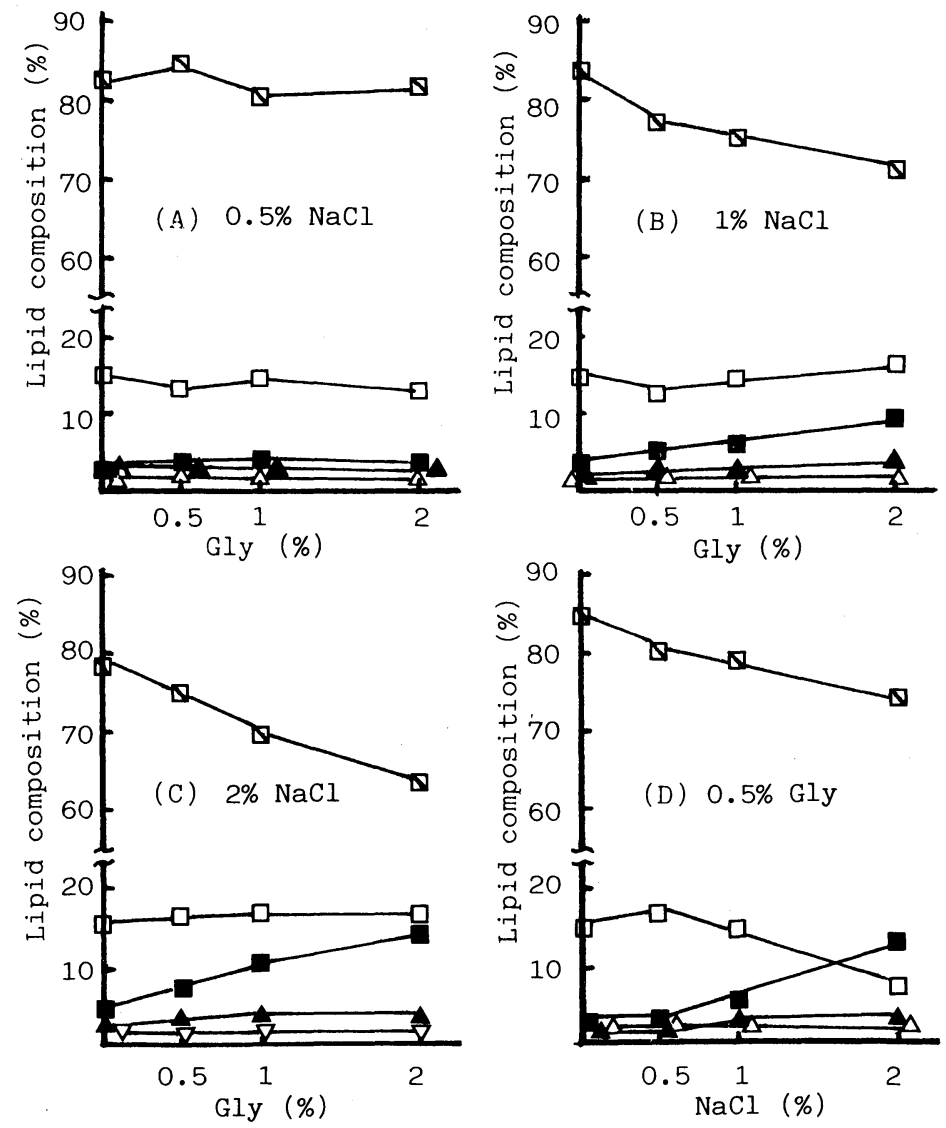

Fig. 4. Lipid composition of $E$. coli grown in sodium chloride or glycine containing medium (A), (B), (C): treatment with glycine of cells grown in $0.5,1,2 \%$ sodium chloride containing medium; (D): treatment with sodium chloride of cells grown in $0.5 \%$ glycine Abbreviations are similar as shown in Fig. 3.

に塗布した $5 \times 20 \mathrm{~cm}$ のガラス板を用い，脂質試料 10 $\mu \mathrm{l}$ を添加した後，それに重ねてE. coli より抽出した非 放射化脂質の濃厚溶液（約 $10 \mathrm{mg} / \mathrm{ml}$ )，4 $4 \mu$ を添加し た. 展開溶媒としては, クロロホルム:メタノール:酢酸 $=65: 25: 10$ を用い, 約 $18 \mathrm{~cm}$ 展開後, 十分に溶媒を除 去し, ヨウ素蒸気で脂質の検出を行った. 粉末が飛ばな いように水を噴霧した後, 各スポットをかきとり, DPO を $4 \mathrm{~g} / 1$ 含むトルエン $8 \mathrm{ml}$ を加え, 各スポットの放射 活性を液体シンチレーションカウンター（アロカLSC90）で測定した。 結果は各脂質のパーセントで示した.

\section{6. 脂肪酸分析}

対数增殖期中期まで培養した菌を集菌・洗浄後， 0.05 $M$ リン酸緩衝液 $(\mathrm{pH} 7.0)$ に OD 660 值が 0.4 になるよ うに懸濁してグリシンや $\mathrm{NaCl}$ による処理を $30^{\circ}$ で 1 時 間行った後, 常法 ${ }^{4}$ に従い脂質を抽出した. この脂質画分 から溶媒を窒素ガスで除去し， $0.1 M$ ナトリウムメチラ 一トでメチル化を行った， 1 時間後, 酢酸を加えて反応
を停止させ，脂肪酸メチルエステルを石油エーテルで抽 出後, 濃縮し, ガスクロマトグラフィーにより分析した。 測定条件は次のとおりである.

装 置：島津製作所製ガスクロマトグラフ GC-4B カラム：ステンレスカラム（長さ $2 \mathrm{~m}$, 内径 $3 \mathrm{~mm}$ ) 充てん剂: 10\% DEGS (Shimalite W)

カラム温度： $180^{\circ}$

検出器：水素炎イオン化検出器

キャリアーガス：窒素ガス

キャリアーガス流速： $45 \mathrm{ml} / \mathrm{min}$

脂肪酸の同定は標準品との保持時間の比較，及び $E$. coli $\mathrm{K}-12$ の脂肪酸組成データ ${ }^{5)}$ との比較によって行っ た.

\section{実験結果及び考察}

\section{1. 膜タンパク質の組成に及ぼすグリシン及び $\mathrm{NaCl}$} の影響

Fig. 1 にグリシン処理菌体から調製したスフェロプ 
Table. 1. Composition of Fatty Acid of Escherichia coli IFO3301

\begin{tabular}{|c|c|c|c|c|c|c|c|c|}
\hline \multirow{2}{*}{ Culture } & \multirow{2}{*}{ Treatment } & \multicolumn{7}{|c|}{ Fatty acid composition (\%) } \\
\hline & & $14: 0$ & $15: 0$ & $16: 0$ & $16: 1$ & $17: 0$ & $18: 1$ & $19: 0$ \\
\hline $\begin{array}{l}\text { Nutrient } \\
\text { broth }\end{array}$ & None & 1.4 & 0.5 & 22.4 & 27.3 & 5.7 & 41.6 & 0.7 \\
\hline $\begin{array}{l}0.5 \% \\
\mathrm{NaCl}- \\
\text { nutrient } \\
\text { broth }\end{array}$ & $\begin{array}{c}\text { Control } \\
\text { Glycine } \\
0.5 \% \\
1.0 \% \\
2.0 \% \\
\end{array}$ & $\begin{array}{l}1.2 \\
\\
1.2 \\
1.2 \\
1.2 \\
\end{array}$ & $\begin{array}{l}0.5 \\
\\
0.5 \\
0.3 \\
0.4\end{array}$ & $\begin{array}{l}22.9 \\
\\
21.5 \\
22.1 \\
22.8 \\
\end{array}$ & $\begin{array}{l}23.4 \\
\\
23.9 \\
23.8 \\
24.9 \\
\end{array}$ & $\begin{array}{l}7.3 \\
7.3 \\
6.8 \\
\end{array}$ & $\begin{array}{l}43.4 \\
44.6 \\
44.1 \\
42.3 \\
\end{array}$ & $\begin{array}{l}1.1 \\
1.3 \\
1.2 \\
\end{array}$ \\
\hline $\begin{array}{l}2.0 \% \\
\mathrm{NaCl}- \\
\text { nutrient } \\
\text { broth }\end{array}$ & $\begin{array}{c}\text { Control } \\
\text { Glycine } \\
0.5 \% \\
1.0 \% \\
2.0 \% \\
\end{array}$ & $\begin{array}{l}1.2 \\
\\
1.2 \\
1.4 \\
1.4 \\
\end{array}$ & $\begin{array}{l}0.2 \\
\\
0.5 \\
0.7 \\
0.7\end{array}$ & $\begin{array}{l}27.2 \\
\\
26.8 \\
27.0 \\
24.5\end{array}$ & $\begin{array}{l}27.1 \\
26.0 \\
28.0\end{array}$ & $\begin{array}{l}6.1 \\
6.6 \\
6.2\end{array}$ & $\begin{array}{l}37.1 \\
37.3 \\
37.6 \\
38.2\end{array}$ & $\begin{array}{l}1.0 \\
\\
1.0 \\
1.0 \\
1.1\end{array}$ \\
\hline $\begin{array}{l}0.5 \% \\
\text { Glycine } \\
\text { nutrient } \\
\text { broth }\end{array}$ & $\begin{array}{l}\text { Control } \\
\mathrm{NaCl} \\
1.0 \% \\
2.0 \% \\
3.0 \%\end{array}$ & $\begin{array}{l}1.0 \\
1.0 \\
1.0\end{array}$ & $\begin{array}{l}0.5 \\
0.7 \\
0.3\end{array}$ & $\begin{array}{l}20.4 \\
20.0 \\
18.9\end{array}$ & $\begin{array}{l}23.2 \\
23.6 \\
24.4\end{array}$ & $\begin{array}{l}5.1 \\
4.5 \\
4.4\end{array}$ & $\begin{array}{l}48.5 \\
49.0 \\
50.1\end{array}$ & $\begin{array}{l}1.3 \\
1.2 \\
1.1\end{array}$ \\
\hline
\end{tabular}

ラスト膜タンパク質の SDS-PAGE の結果を, Fig. 2 に $2 \% \mathrm{NaCl}$ 含有培地増殖菌のグリシン処理の場合の SDSPAGE の結果を示した. これらの処理により, 菌体成分 の漏出 ${ }^{1)}$ や溶菌 ${ }^{6}$ が観察されたが, 膜タンパク質の組成に は全く変化は見いだせなかった，また $\mathrm{NaCl}$ 処理菌，グ リシンと $\mathrm{NaCl}$ の併用処理菌, グリシン含有培地増殖菌 の $\mathrm{NaCl}$ 処理菌などからもスフェロプラストを調製し膜 タンパク質の SDS-PAGE を行ったが，これらにも全く 変化がなかったため, 結果は省略した。

\section{2. リン脂質組成に及ぼすグリシン及び $\mathrm{NaCl}$ の影響}

グリシンあるいは $\mathrm{NaCl}$ の単独処理, 及びグリシンと $\mathrm{NaCl}$ の併用処理を行った菌体のリン脂質組成を Fig. 3 に示した。菌体を $\mathrm{NaCl}$ で処理した場合, 処理濃度が高 くなるにつれてホスファチジルエタノールアミン $(\mathrm{PE})$, ホスファチジルグリセロール (PG) の含有率が低下し, 逆にカルジオリピン (CL), 遊離脂肪酸 (FFA) の含有率 が上昇した (Fig. 3(A)). しかし，グリシン単独で処理し た場合は, リン脂質組成の変化は全く認められなかった (Fig. 3(B)). グリシンと $\mathrm{NaCl}$ の併用処理の場合 (Fig. 3 (C)) は, $\mathrm{NaCl}$ 単独処理の場合之同様の傾向, すなわち $\mathrm{PE}, \mathrm{PG}$ 含有率の低下と, $\mathrm{CL}, \mathrm{FFA}$ 含有率の上昇が認め られ，特に，CL含有率の上昇が著しかった.

$\mathrm{NaCl}$ 含有培地で増殖した菌をグリシンで処理した場 合, 及びグリシン添加培地で増殖した菌を $\mathrm{NaCl}$ で処理 した場合のリン脂質組成の変化を Fig. 4(A)〜(D) に示し た. $\mathrm{NaCl}$ 含有培地で増殖した菌をグリシンで処理した 場合，処理したグリシンの濃度が上がるのに従い, $\mathrm{PE}$
が減少し, FFA が増加したが, CL の増加は認められな かった (Fig. 4(B), (C)). またグリシン添加培地で増殖し た菌を $\mathrm{NaCl}$ で処理した場合 (Fig. 4(D)) には, PE, PG の減少と FFA の増加が認められた。

大腸菌のリン脂質は 70～80\%を占める $\mathrm{PE}, 10 \sim 20 \%$ の PG 及び数パーセントの CL から成っており ${ }^{7), 8)}$ ，さま ざまな条件によりその組成比は変化する ${ }^{9), 10)}$. また Staphylococcus aureus では培地中の $\mathrm{NaCl}$ の濃度に応じて CL が増加することが知られており，この菌の強い耐塩 性との関連が示唆されている ${ }^{11)}$. グリシン単独で処理し た場合，脂質組成比に変化はなかったが， $\mathrm{NaCl}$ 処理の 場合, PEと PG が減少し, CL, FFA が増加することが 認められ，グリシンと $\mathrm{NaCl}$ を併用処理するとその傾向 がより顕著になった。 ところが， $\mathrm{NaCl}$ 添加培地で増殖 した菌あるいはグリシン添加培地で増殖した菌を，それ ぞれグリシンあるいは $\mathrm{NaCl}$ で処理すると, CL の増加 は全く認められず, FFAのみが増加していた.

環境条件の変化に対応して微生物がそのリン脂質組成 を変化させることはよく知られており ${ }^{9 / 11)}$ ，一般に PG が減少して CL が増加することが多い. CL は PG2 分子 から合成され，その反応にはエネルギーを要しないと考 えられている ${ }^{12)}$. つまり CL の増加は比較的簡単に微生 物が環境に適応する場合に見られる反応であると考える ことができる. 逆に, FFA の増加は膜を構成しているリ ン脂質の分解を示すむのであり，この反応が進めば溶菌 など菌体にとって致命的な結果となることが考えられ る. 
膜の保持の点から考えても, CL の増加は膜を堅く安

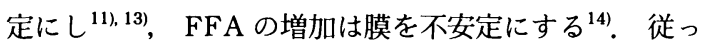
て, グリシンと $\mathrm{NaCl}$ の併用処理 (Fig. 3(C)) において は, FFA の増加という膜の不安定化要因は認められる ものの, CL の増加という膜の安定化要因のほうが上回 っているため, グリシンによる溶菌や菌体成分の漏出が 抑えられるものと推察できる。，逆に， $\mathrm{NaCl}$ 添加培地増 殖菌をグリシンで処理した場合 (Fig. 4(B), (C)) はCL の 増加は認められず, FFA のみが増加し, 膜が不安定にな っていると考えられ，このことが抗菌力の併用効果と関 係していることが推察された. また, グリシン添加培地 増殖菌を $\mathrm{NaCl}$ で処理した場合 (Fig. 4(D)) あ, CL は増 加せず, FFA が増加していたが, この処理では菌体表層 の損傷は起こるが, 菌体成分の漏出はほとんど認められ ないなど矛盾した結果 ${ }^{1}$ であった。

\section{3. 脂肪酸組成に及ぼすグリシン及び $\mathrm{NaCl}$ の影響}

Table 1 に各処理菌の脂肪酸組成比を示した. それぞ れの培地条件内では，グリシン処理や $\mathrm{NaCl}$ 処理によっ て脂肪酸組成比はほとんど変わらないが, 培地条件が異 なった場合, 明らかにその組成比は異なっていた. 主脂 肪酸である $16: 0,16: 1,18: 1$ について比較すると, $0.5 \% \mathrm{NaCl}$ 添加培地増殖菌が最も対照区の組成比と近 く, $2 \% \mathrm{NaCl}$ 添加培地増殖菌では飽和酸, $16: 0$ の含量 が高く, 不飽和酸, 特に $18: 1$ の含量が低かったが, 逆 に $0.5 \%$ グリシン添加培地増殖菌では $16: 0$ の含量が低 く, 18:1の含有率が上昇していた.

微生物が外界の温度变化に適応して膜リン脂質の脂肪 酸組成をすみやかに変化させ, 膜の流動性を一定に保つ ことはよく知られている ${ }^{15), 16)}$. 一般に環境温度が低い場 合には, 不飽和酸を増大させ, 温度が高くなれば, 飽和 酸を増大させて膜の流動性を一定に保つが, この変化が 同一温度で起こるとすると, 不飽和酸の多い膜は柔らか く, 飽和酸の多い膜は堅くなる.このような脂肪酸組成 比から, 本実験の結果を見ると, $\mathrm{NaCl}$ 添加培地増殖菌 では膜は堅く，グリシン添加培地増殖菌では膜は柔らか くなっていると考えられるが, 前者のグリシン処理ある いは後者の $\mathrm{NaCl}$ 処理によっては, 脂肪酸組成は変化せ ず, 抗菌力併用効果発現との関連性は薄いものと判断し た.

\section{要 約}

グリシンと $\mathrm{NaCl}$ の抗菌力併用効果について, 菌体表 層とくに膜の損傷が示唆されたので, 膜構成成分のタン
パク質, 脂質の変化を調べ, 次のような結果を得た.

1. 菌体成分の漏出や溶菌が観察される条件によって も, 膜タンパク質の組成は変化せず，抗菌力併用効果之 の関連は見いだせなかった。

2. 膜脂質の脂肪酸は $\mathrm{NaCl}$ 含有培地での増殖あるい はグリシン含有培地での増殖など培地条件により変化す るが，前者のグリシン処理，後者の $\mathrm{NaCl}$ 処理などでは 全く変化せず, 抗菌力発現との関連は薄いと推察した。

3. 膜リン脂質の組成は，グリシンの抗菌力に対して 抑制的に働く $\mathrm{NaCl}$ との併用処理では, 菌体の環境適応 の一つである CL の増加が目立ち, グリシンと $\mathrm{NaCl}$ の 抗菌力併用効果が現れる処理では, 膜リン脂質の崩壊を 示すFFA が増加し, 抗菌力発現との関連が認められた.

文献

1) 竜口和恵, 坂本次郎, 李 在根, 堤 將和: 食衛誌. 30 , 506 511 (1989).

2) Miura, T., Mizushima, S.: Biochim. Biophys. Acta 193, 268 276 (1969).

3) Lugtenberg, B., Meijers, J., Perters, R., Hoek, P. van, Alphen, L. van: FEBS Lett. 58, 254 258 (1975).

4) Bligh, E. G., Dyer, W. J.: Can. J. Biochem. Physiol. 37, 911 917 (1959).

5) Silbert, D. F., Ruch, F., Vagelos, P. R.: J. Bacteriol. 95, $1,658 \sim 1,665$ (1968).

6) 李 在根, 竜口和恵, 堤 將和, 渡辺忠雄: 食衛誌. 26 , 279 284 (1985).

7) Ames, G. F.: J. Bacteriol. 95, 833 843 (1968).

8) Chamberlain, B. K., Webster, R. E.: J. Biol. Chem. 251, 7,739 7,745 (1976).

9) Okuyama, H.: Biochim. Biophys. Acta 176, 125 134 (1969).

10) Chiu, T-H., Hung, S-A.: ibid.558, 267 272 (1979).

11) Kanemasa, Y., Yoshioka, T., Hayashi, H.: ibid. 280, $444 \sim 450$ (1972).

12) Hirschberg, C. B., Kennedy, E. P.: Proc. Nat. Acad. Sci. 69, 648 651 (1972).

13) Hayami, M., Okabe, A., Kariyama, R., Abe, M., Kanemasa, Y.: Microbiol. Immunol., 23, 435 442 (1979).

14) Gordon, A. S., Wallch, D. F. H., Staraus, J. H.: Biochim. Biophys. Acta 183, 405 412 (1965).

15) Marr, A. G., Ingraham, J. L.: J. Bacteriol. 84, 1,260 1,267 (1962).

16) De Siervo, A. J.: ibid. 100, 1,342 1,349 (1969). 